\title{
Výzkum významných zdrojů česko-saských přeshraničních podzemních vod
}

\section{PAVEL ECKHARDT, DAVID ROZMAN, ZBYNĚK HRKAL, ONDŘEJ NOL}

Klíčová slova: matematický model - podzemní vody - využívání podzemních vod - ochrana podzemních vod

\section{SOUHRN}

Zajímavým a užitečným tématem, které je možné řešit v rámci Evropské unie, je problematika přeshraničních podzemních vod. Podzemní vody jsou jako důležité vodní zdroje často využívány na obou stranách společné státní hranice, a proto může docházet $k$ jejich preshraničnímu ovlivnění. Na společnou ochranu významných oblastí podzemních vod v česko-saské príhraniční oblasti byl zaměřen mezinárodní projekt ResiBil probíhající v letech 2016-2020. Jako zájmové území uvedeného projektu byly vybrány oblasti křídových sedimentů Děčínského Sněžníku, Česko-saského Švýcarska a Lužických hor. Cílem projektu ResiBil bylo stanovení bilance, zhodnocení možnosti dlouhodobého využívání zdrojů podzemních vod a udržitelného hospodaření s nimi v závislosti na očekávaných dopadech vlivu klimatických změn. Z provedených studií a modelů vyplynulo, že důvodem změn vodního režimu a vodní bilance $v$ krajině jsou $\checkmark$ různé míre jak klimatické vlivy, tak i vlivy antropogenní. Využití podzemních vod však má v zájmových oblastech významné rezervy.

\section{ÚVOD}

ResiBil je mezinárodní projekt podporovaný Evropským fondem pro regionální rozvoj z Programu podpory přeshraniční spolupráce Česká republika - Svobodný stát Sasko 2014-2020, registrovaný pod číslem 100267011, a Ministerstvem životního prostředí. Projekt probíhal v letech 2016 až 2020.

Na řešení geologických a hydrogeologických podkladů se jako hlavní partner podílela německá strana zastoupená Saským zemským úřadem pro životní prostředí, zemědělství a geologii (LfULG) a na české straně projektoví partneři reprezentovaní Českou geologickou službou (ČGS) a Výzkumným ústavem vodohospodářským T. G. Masaryka, v. v. i. (VúV TGM).

Projekt byl zaměřený na společnou ochranu podzemních vod v česko-saské příhraniční oblasti mimo jiné na základě využití moderních modelových prostředků.

\section{METODIKA}

\section{Charakteristika projektového území a přehled prací}

Pro projektové práce byly vybrány dưležité oblasti významných výskytů přeshraničních podzemních vod. Ty se v zájmovém česko-saském přeshraničním území nacházejí zejména v oblastech silně propustných křídových sedimentů v rámci české křídové pánve [1]. Ostatní česko-saské přeshraniční území je tvořeno horninami krystalinika, které jsou méně hydrogeologicky významné.
V zájmovém území byly vyčleněny tři pilotní oblasti: Děčínský Sněžník, Hřensko-Křinice/Kirnitzsch (oblast Česko-saského Švýcarska) a Lückendorf (oblast Lužických hor). Původně plánovaný rozsah pilotních oblastí při předložení projektu byl menší (černé linie na obr. 1), avšak z důvodu potřeby vytvoření rozsáhlejších hydrogeologických modelů byly oblasti rozšířeny (plochy s červenou, modrou a žlutou šrafou), jak znázorňuje obr. 1 .

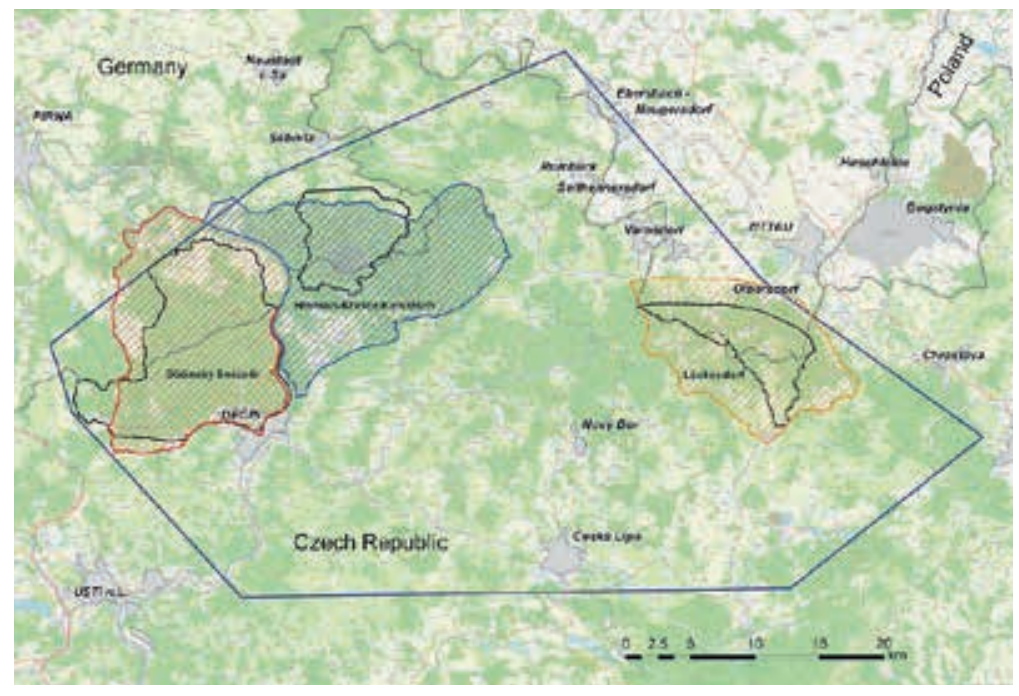

Obr. 1. Mapa zájmového území (modrá linka) a modelových oblastí projektu ResiBil Fig. 1. Map of the ResiBil project region (blue line) and model areas

Prostřednictvím projektu byl vytvořen systém navazujících modelů, který přispěl k hlubšímu poznání území a k zodpovězení společných otázek v oblasti odhadů zásob, vodohospodářského plánovaní a institucionální spolupráce. Cílem je efektivní využívání podzemních vod a jejich přeshraniční ochrana.

Základem dalších prací bylo sestavení jednotného přeshraničního geologického 3D modelu, vytvořeného ČGS ve spolupráci s LfULG. Sjednocení různých interpretací geologické stavby na obou stranách státní hranice bylo nezbytnou podmínkou pro navazující sestavení konceptuálního 3D hydrogeologického modelu. Pro jeho návrh byla použita série dva roky probíhajících prípravných terénních prací, které se zaměřly na geometrické vymezení hlavních kolektorů a izolátorů a získání kvantitativních charakteristik. Pro tyto účely byly mj. realizovány dva průzkumné hydrogeologické vrty, které byly po aplikaci komplexních karotážních metod přeměněny na vrty monitorující hladinu podzemní vody. $\checkmark$ rámci terénních prací byla provedena podrobná inventarizace pramenních vývěrů a pro modelové řešení byly na vybraných vodních tocích změřeny tzv. postupné profilové průtoky. Jako jeden ze vstupů do hydraulického modelu byl 


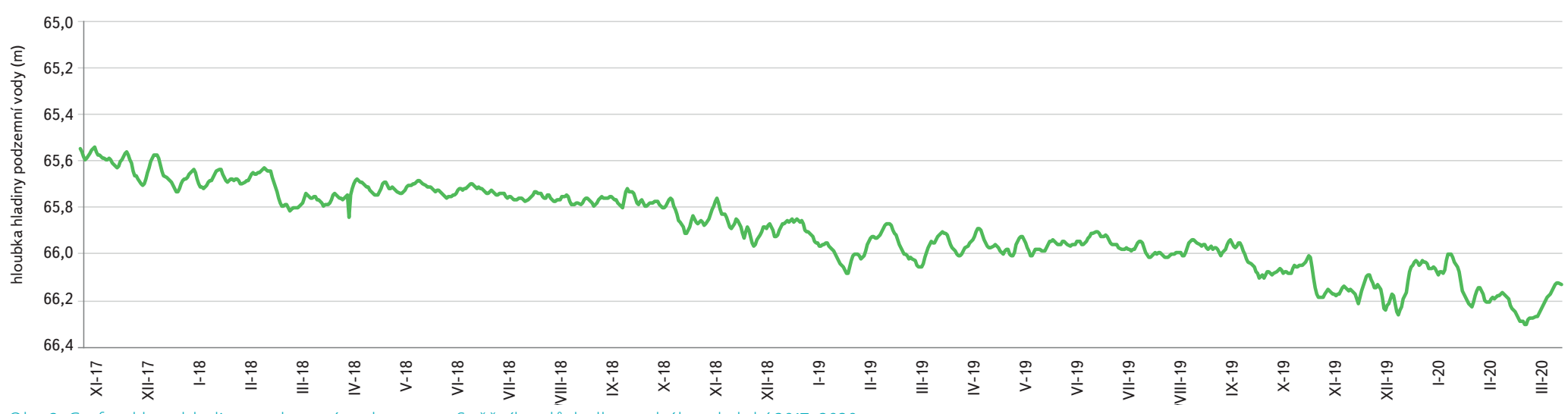

Obr. 2. Graf poklesu hladiny podzemní vody ve vrtu Sněžník v dưsledku suchého období 2017-2020

Fig. 2. Graph of groundwater level decrease in borehole Sněžník in dry period 2017-2020

sestaven hydrologický bilanční model a vytvořena databáze významných jímaných vodohospodářských objektů zahrnující časové řady jejich využití.

Z těchto podkladových materiálů byly sestaveny hydraulické modely, které byly následně kalibrovány na historická data a staly se nástrojem pro simulace dalšího vývoje. Finálním výstupem byla simulace různých variant vývoje sledovaných vodohospodářských struktur a kalkulace využitelných zásob podzemní vody. Následující text představuje výběr výsledků těchto postupů v námi zpracovávaných územích Děčínského Sněžníku a Česko-saského Švýcarska.

\section{TERÉNNÍ HYDROGEOLOGICKÉ PRÁCE}

\section{Hydrogeologické vrtné práce}

V rámci průzkumných hydrogeologických prací byla nejprve provedena podrobná rešerše všech dosud uskutečněných hydrogeologických vrtných prací. Plošná a prostorová interpretace dat umožnila definovat prostor nejistot, tzn. prostředí, kde pro definování konceptuálního modelu chyběla potřebná data. Mezi tato území spadala především oblast severní (příhraniční) části českého území Děčínského Sněžníku. Zde byly vyprojektovány dva průzkumné hydrogeologické vrty, které byly realizovány $\vee$ zárí 2017. Vrty byly situovány v blízkosti státní hranice v lokalitách Sněžník a Maxičky, dosáhly hloubky 99 a 102 metrů. Byly konstruovány k průzkumu hlavního (turonského) kolektoru. Hladiny podzemní vody byly, vlivem morfologie a vysoké propustnosti prostředí, zastiženy až v hloubkách přes 60 metrů pod terénem.

Oba vrty byly osazeny automatickým datalogerem na kontinuální měření hladiny podzemní vody. Tato data byla následně využita při kalibraci modelů. Obrázek 2 demonstruje ukázku zaznamenaného postupného poklesu hladiny podzemní vody v monitorovacím vrtu RE 001 Sněžník v důsledku období sucha v letech 2017 až 2020.

\section{Karotáž}

Na obou vrtech byly realizovány dvě etapy karotážních měěení, první byla provedena pred definitivním vystrojením vrtu, druhá po jeho dokončení.

Cílem měření prè výstrojí bylo detailně rozčlenit litologický profil, zjistit prostorový průběh vrtů (odklon od vertikály a azimut odklonu), zjistit úseky vykavernované horniny, identifikovat otevřené pukliny a zjistit základní fyzikální vlastnosti zastižených hornin. K tomu byly použity tyto karotážní metody: gama gama karotáž v hustotní modifikaci, kavernometrie, gama karotáž, neutron neutron karotáž, karotáž magnetické susceptibility, odporová karotáž, indukční karotáž, inklinometrie.

Cílem měření po vystrojení bylo objasnit hydrodynamické poměry ve vrtech, zjistit fyzikálně-chemické vlastnosti vody a jejich prípadnou zonalitu a zkontrolovat kvalitu provedení vrtů. Pro to byly použity následující karotážní metody: televizní prohlídka vrtnou kamerou, citlivá termometrie, rezistivimetrie $\checkmark$ aplikaci metody ředění označené kapaliny, rezistivimetrie $v$ aplikaci metody konstantního čerpání označené kapaliny, gama gama karotáž v hustotní modifikaci, kavernometrie, hloubkově spojité měření fyzikálně-chemických vlastností vody - konduktivity, teploty, pH, redox potenciálu a procenta rozpuštěného kyslíku.

Zastiženy byly sedimenty svrchnokřídového stárí (turon) v písčitém a jílovitopísčitém vývoji. Na základě karotáže byl podrobně rozčleněn litologický profil. Bylo zastiženo souvrství sedimentů, jež mírně upadá směrem k severovýchodu. Vrstvy se v obou vrtech opakují, ve vrtu Maxičky jsou však o 58,5 m níže v porovnání s vrtem Sněžník.

Diametrálně se liší hydrodynamický režim v obou vrtech. Zatímco ve vrtu Maxičky dochází jen $k$ velmi pomalému proudění od hladiny směrem dolů $(0,002 \mathrm{l} / \mathrm{s})$, ve vrtu Sněžník bylo zjištěno velmi intenzivní proudění vody. To napříč vrtem dosahuje rychlosti 29,5 m/den, intenzivní je i vertikální složka proudění $(1,0 \mathrm{l} / \mathrm{s})$. Rozdíly mezi oběma vrty tak dokládají mj. významný podíl puklinové propustnosti v daném prostředí.

\section{Měření průtoků vodotečí}

Hydrogeologické poměry mohou být upřesněny charakterizací povrchových vodotečí. Kolektory podzemních vod jsou většinou propojeny s toky $v$ daném území, do kterých se podzemní vody odvodňují, nebo se z nich naopak doplňují infiltrací. Platí, že pokud je hladina podzemní vody v kolektoru výše než hladina ve vodoteči, dochází k odvodnění kolektoru, a pokud je hladina podzemní vody níže, dochází k dotaci kolektoru.

Odvodnění kolektoru Ize specifikovat jako základní odtok vodoteče. Jde o průtok v delším období bez srážek, kdy ve vodoteči už není voda pocházející z povrchového odtoku srážek, ale pouze voda původem z podzemního odtoku z okolních kolektorů. Pokud základní odtok změříme na několika profilech vodoteče, zjistíme intenzitu odvodnění nebo dotace kolektoru pro každý úsek mezi dvěma měřeními. Takové měření nazýváme postupné podélné profilování (PPP). Tímto způsobem můžeme poměrně přesně určit prítoky a odtoky z dané hydrogeologické struktury. Príklad takového provedeného preshraničního 
měření uvádíme na obr. 3 (zobrazené hodnoty průtoků jsou v l/s). Z obr. 3 jsou patrné často násobné rozdíly dotace podzemních vod do vodotečí v měřených úsecích, část menších vodotečí byla v době měření bez vody.

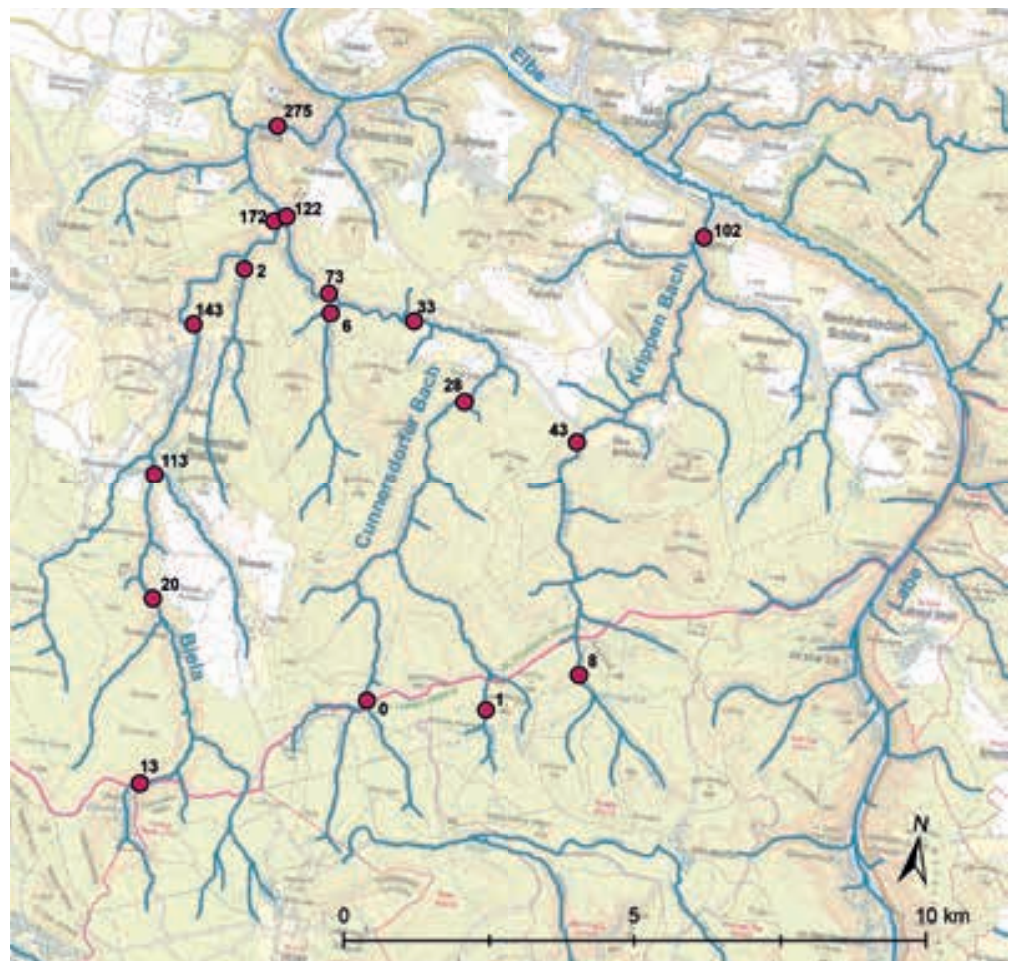

Obr. 3. Př́klad provedení měření průtoků metodou PPP v oblasti Děčínského Sněžníku Fig. 3. Sample of flow measurement in Děčínský Sněžník region

\section{Evidence a měření pramenních vývěrů}

Pramen je vývěr podzemní vody na povrch. Evidence a měření pramenů patří mezi základní možnosti získání hydrogeologických informací v terénu. Prameny poskytují důležité údaje o stavu a změnách hydrogeologického prostředí. Pramenů existuje $v$ daném území početně podstatně více než využitelných hydrogeologických vrtů.

Pro modelová řešení indikují prameny místa či linie odvodňování jednotlivých kolektorů, ale zejména mohou být podkladem k přesnějšímu vymezení izolátorů a poloizolátorů. Prameny mohou upozornit i na některé jinak hůře podchytitelné jevy, jakým je třeba detailní stratifikace kolektorů.

Základním podkladem pro další práce bylo provedení rešerše odborných materiálů $\mathrm{k}$ dané problematice, následovalo mapování pramenů $v$ terénu. $U$ všech nalezených pramenů byla měřna vydatnost, konduktivita vody, aktuální teplota vody a vzduchu, poloha pramene a byla provedena fotodokumentace. $V$ každé z oblastí bylo nalezeno a změřeno více než 150 pramenů. Jejich vydatnosti se pohybují v širokém rozmezí od tisícin I/s přes běžné vydatnosti $\checkmark$ desetinách I/s až po maximálních více než 10 litrů za sekundu. Část nadprůměrně vydatných pramenů je využívána k zásobování obyvatel pitnou vodou (např. Vlčí a Studený pramen v oblasti Děčínského Sněžníku nebo pramen Pod Pravčickou bránou v oblasti Hřenska).

Pomocí evidence a měření pramenů se podařilo mj. vymezit a upřesnit důležité hydrogeologické struktury pro modelová řešení. Jednalo se například o polohy jednotlivých izolátorů jako bazální křídový izolátor a izolátor A/BC $\checkmark$ části oblasti Děčínský Sněžník. V oblasti Hřensko-Křinice byl pomocí pramenních vývěrů upřesněn rozsah (polo)izolátoru 2/3, respektive rozhraní kolektorů 2 a 3 v sedimentech turonu.

\section{MATEMATICKÉ MODELOVÁNÍ}

V rámci projektu bylo $k$ dosažení cílů využito souboru moderních modelových prostředků, část z nich představuje následující text. Modelování a bilancování podzemních vod navazovalo na předchozí práce napríklad [2, 3].

\section{Hydrologické bilanční modelování}

Infiltrace srážek a doplňování kolektorů bylo vyhodnoceno pomocí hydrologického modelu BILAN, který simuluje složky vodní bilance $v$ daném povodí. Model byl vyvinut ve VúV TGM (popsán v publikaci [4]). Struktura modelu vychází ze systému rovnic, které popisují vodní bilanci.

Hydrologické modely byly zpracovány pro jednotlivá povodí, která jsou vymezená podle dostupných časových řad průtoků. Pro vybrané profily jsou pomocí digitálního modelu terénu vymezené plochy príslušných povodí. Následně byly pro každé povodí připravené časové řady srážek a teplot. Hodnoty reprezentativní pro jednotlivá povodí jsou výsledkem interpolace hodnot z meteorologických stanic v povodí nebo v jeho okolí.

\section{Konceptuální model}

Konceptuální model je významným krokem při tvorbě hydraulického numerického modelu. Představuje interpretaci hydrogeologických a souvisejících geologických, geomorfologických, hydrochemických a klimatických poměrů hydrogeologického celku, směrů proudění, vyjasnění míst infiltrace a drenáže, a to včetně stanovení okrajových podmínek.

Významné křídové kolektory $\vee$ zájmovém území tvoří obecně pískovce, zatímco ostatní litologické typy s větším podílem jílu a prachu tvoří izolátory a poloizolátory. Hydrogeologický konceptuální model území rozlišuje čtyři oddělené kolektory s tím, že $v$ některých modelových částech se nemusí všechny zmíněné kolektory vyskytovat:

Modelový kolektor 4, neboli kolektor A, představuje bazální křídový kolektor. Jeho mocnost dosahuje $k 80$ m na Děčínském Sněžníku a až 140 m u lužické poruchy na severu zájmového území.

Hlavní křídový kolektor BC s nejvýznamnějšími odběry podzemní vody $\checkmark$ oblasti se $v$ severní části zájmového území dělí na spodnější kolektor 3 a svrchní kolektor 2. Izolátor mezi kolektory 3 a 2 (3/2) je lépe definován na severu - v saské části v povodí Křinice. V navazujících částech zájmového území izolátor postupně ztrácí svoji funkci. Jižně od toku řeky Kamenice a v oblasti Děčínského Sněžníku se tento izolátor již významně neprojevuje. Proto v těchto částech konceptuální model předpokládá spojený kolektor $2+3$ (BC). Jeho mocnost dosahuje až $230 \mathrm{~m}$.

Kolektor 2 je definován v pískovcích středního turonu, byl vymezen v SZ části oblasti Hřensko-Křinice nad izolátorem 3/2. Kolektor 1 (D) predstavuje menší, často nesouvislé výskyty, zejména svrchnokř́idových pískovců, ale i kvartérních sedimentů, má většinou jen lokální význam. Na většině zájmové oblasti jsou svrchní tři kolektory modelované jako kombinované.

Ukázku okrajových podmínek a modelových hladin podzemních vod představuje mapa na obr. 4.

\section{Hydraulické modely}

Jako nástroj pro matematické modelování byl v prrípadě oblastí Děčínský Sněžník a Hřensko-Křinice použit proudový model MODFLOW [5]. Je to trojrozměrný model založený na metodě konečných diferencí. Modelovaná oblast se nejprve vertikálně rozdělí do vrstev a uvnitř těchto vrstev se definuji elementy 


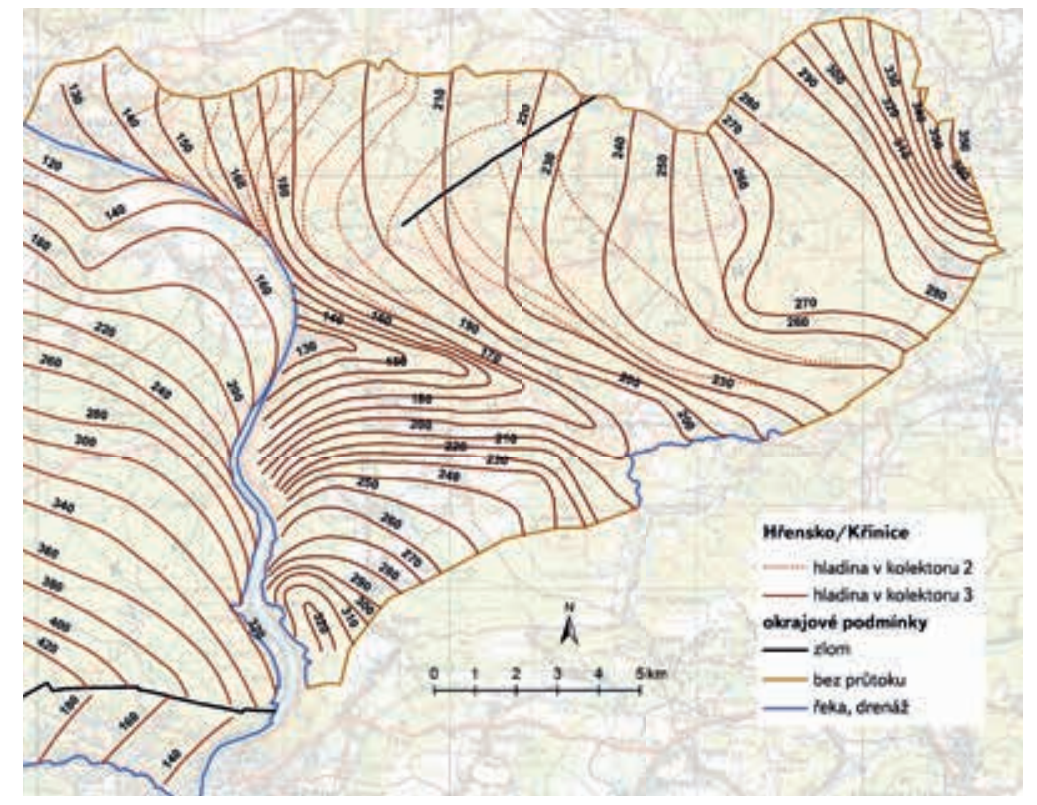

Obr. 4. Mapa okrajových podmínek a hladin podzemních vod v okolí Labe

Fig. 4. Map of boundary conditions and groundwater levels near the Labe River

o obdélníkové základně. V modelované oblasti je možné definovat zdroje a odběry vody, jako jsou plošné zdroje ze srážek, evapotranspirace, čerpané studny, drenáže, vodní toky.

Hydraulický model byl v oblasti Hřensko-Křinice sestaven jako sedmivrstevný, zahrnul čtyr̆i kolektory a tři (polo)izolátory. V oblasti Děčínského Sněžníku byl hydraulický model sestaven jako šestivrstevný, vzhledem k odlišným podmínkám na jihu a v rozsáhlejší severní části, obě části oblasti jsou oddělené děčínským zlomem.

Výsledky hydraulických modelů byly kalibrovány daty o reálném průběhu hladin podzemních vod, bylo simulováno proudění podzemní vody, byly podchyceny vlivy čerpání a infiltrace na režim a stav podzemních vod. Byl proveden výpočet prírodních zdrojů a využitelného množství podzemní vody.

\section{VÝSLEDKY MODELOVÝCH SIMULACÍ}

Výslednou etapou prací bylo využití vytvořených nástrojů - matematických hydraulických modelů pro simulace dalšího vývoje zkoumaných hydrogeologických struktur. K dispozici byly klimatické scénáře, které vycházejí z dat IPCC, založené na předpokladu trvalého oteplování. Po zadání předpokládaných teplotních změn do srážkoodtokových modelů můžeme připravit modelové předpovědi, které predikují pokles efektivní infiltrace. Tento pokles jde na vrub zvýšení hodnoty výparu a transpirace vegetačním pokryvem. Po zvážení nejistot jsme se rozhodli realizovat vodohospodářskou prognózu s výhledem 30 let.

Modely bylo simulováno celkem deset scénárư pro každou zkoumanou oblast, které zohlednily varianty možného klimatického vývoje a předpokládané varianty vývoje využívání podzemních vod. Př́klad modelového snížení hladin podzemních vod prí scénáři s vyšší evapotranspirací a vyššími odběry podzemních vod znázorňuje obr. 5.

\section{VÝSLEDKY A DISKUSE}

Přírodní zdroje na území Hřensko-Křinice (oblast Česko-saského Švýcarska) byly modelem ověřeny na 250 mm za rok, což odpovídá 1481 l/s. Využitelné množství, které zajistí nepřetížení hydrogeologické struktury, činí $623 \mathrm{l} / \mathrm{s}$. Při současných odběrech ve výši $105 \mathrm{l} / \mathrm{s}$ jsou disponibilní zdroje podzemní vody $518 \mathrm{l} / \mathrm{s}$.

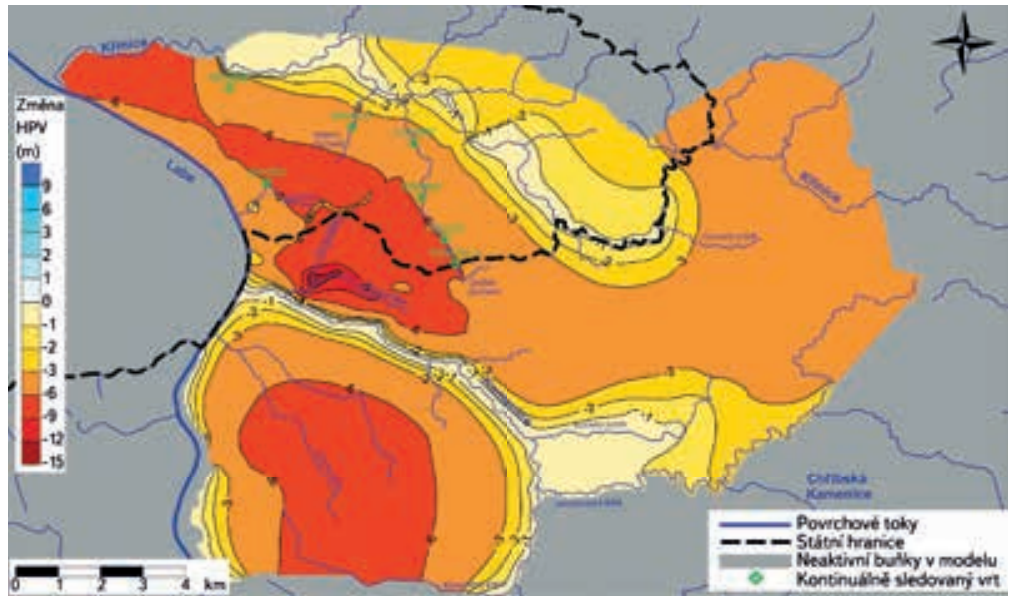

Obr. 5. Modelové snižení hladin podzemních vod na príkladu scénáře s vyššími odběry a vyšší evapotranspirací v oblasti Hřensko-Křinice

Fig. 5. Situation of model scenario groundwater levels decreasing by dry period and

extension of water use in area Hřensko-Křinice

Prírodní zdroje území Děčínského Sněžníku byly modelem ověřeny na 130 mm za rok, což odpovídá 724 l/s. Využitelné množství, které zajistí nepřetížení hydrogeologické struktury, činí $321 \mathrm{l} / \mathrm{s}$. Při současných odběrech ve výši 78 l/s jsou disponibilní zdroje podzemní vody 243 l/s.

Sestavené modely proudění podzemní vody jsou zjednodušenou simulací prírodních procesů. Modelové zátěžové testy prokázaly, že $v$ oblastech Hřensko-Křinice i Děčínský Sněžník by bylo možné zvýšit čerpání maximálních povolených odběrů hlavního turonského kolektoru až na 115 \%, a to i za snižené infiltrace (tedy v suchém období). To by znamenalo pro oblast Hřensko-Křinice na české straně až 125,9 l/s a současně na německé straně $80,5 \mathrm{l} / \mathrm{s}$. Obdobně v oblasti Děčínského Sněžníku by toto zvýšení na české straně mohlo dosáhnout až 106,8 I/s a současně na německé straně $13,8 \mathrm{I} / \mathrm{s}$. V uvedeném prípadě je však treba počítat s poklesy hladin podzemních vod až v rádu vyšších jednotek metrů. Případná navýšení odběrů však mohou mít (přeshraniční) dopady nejen na výši hladin podzemních vod, ale i na poklesy vydatnosti až vysychání některých pramenů či drobných vodotečí. Proto je každý významnější odběr podzemních vod třeba důkladně zvážit. K posouzení mohou napomoci i sestavené modely proudění.

Pro potřeby zásobování obyvatelstva pitnou vodou se v daném území využívá převážně turonský kolektor (BC či 2 + 3), a to pouze ve vybraných oblastech. Vzhledem k tomu, že využití dobře chráněného bazálního křídového kolektoru (A či 4) je zde nízké, v některých oblastech nulové, je možné považovat tento kolektor za významný rezervní zdroj podzemních vod.

\section{ZÁVĚR}

Cílem provedené studie byl výzkum možnosti využití a ochrana preshraničních podzemních vod. Na přeshraničních česko-saských oblastech s významnými zásobami podzemních vod byl realizován podrobný geologický i hydrogeologický průzkum, zahrnující i provedení dvou hlubokých hydrogeologických vrtů.

Na základě získaných poznatků byly sestaveny matematické modely ve stacionárním a později i $v$ transientním režimu. $V$ přeshraničních česko-saských oblastech byly mj. vypočteny prírodní zdroje podzemních vod a ověřeny zdroje využitelné. Modelové zátěžové testy prokázaly možné zvýšení odběrů podzemních vod i za klimaticky nepříznivého vývoje, ovšem za cenu poklesủ hladin podzemních vod, prípadně snižování vydatnosti pramenů. 
Z provedených studií a modelů vyplynulo, že důvodem změn vodního režimu a vodní bilance v krajině jsou v rưzné míre jak klimatické vlivy, tak i vlivy antropogenní, zejména odběry podzemních vod. Ve využívání podzemních vod této oblasti existují významné rezervy.

\section{Poděkování}

Projekt ResiBil byl financován z Evropského fondu pro regionální rozvoj z Programu spolupráce Česká republika - Svobodný stát Sasko 2014-2020, registrovaný pod čílem 100267011.

Přispěvek vznikl za finančního přispění interního grantu Výzkumného ústavu vodohospodárského T. G. Masaryka, v. v. i.

\section{Literatura}

[1] HERČÍK, F., HERMANN, Z. a VALEČKA, J. Hydrogeologie české křidové pánve. Český geologický ústav, Praha, 1999, 118 s. ISBN 80-7075-309-9.

[2] BURDA, J., VENERA, Z. a kol. ID EIS 10051606-SFŽP Rebilance zásob podzemních vod. Závěrečná zpráva. Př́loha č. 2/41. Stanovení zásob podzemních vod. Hydrogeologický rajon 4630 Děčínský Sněžník. ČGS, Praha, 2016

[3] KALINOVÁ, M. a kol. Zdroje podzemnich vod na česko-saském pomezí I. Oblast Hřensko-Křinicel Kirnitzsch. Odborná publikace. VÚV TGM, Praha, 2014, 95 s. ISBN 978-80-87402-30-6.

[4] TALLAKSEN, L.M. and VAN LANNEN, H. Hydrological Drought - Process and Estimation Methods for Streamflow and Groundwater. Elsevier, Amsterdam, 2004.

[5] HARBAUGH, A.W. and MCDONALD, M.G. User's documentation for MODFLOW- 96, an update to the U.S. Geological Survey modular finite-difference ground-water flow model, USGS Open-File Report 96-485. 1996.

\section{Autoři}

Mgr. Pavel Eckhardt ${ }^{1}$

凶pavel.eckhardt@vuv.cz

ORCID: 0000-0002-4218-5344

Mgr. David Rozman ${ }^{1,2}$

凶david.rozman@vuv.cz

ORCID: 0000-0001-9509-3227

doc. RNDr. Zbyněk Hrkal, CSc. ${ }^{1,2}$

凶zbynek.hrkal@vuv.cz

ORCID: 0000-0002-8492-394X

\section{Mgr. Ondřej $\mathrm{Nol}^{3}$}

网 ondrej.nol@geology.cz

ORCID: 0000-0002-0081-8211

'Výzkumný ústav vodohospodářský T. G. Masaryka, v. v. i.

${ }^{2}$ Prírodovědecká fakulta, Univerzita Karlova

${ }^{3}$ Česká geologická služba

Příspěvek prošel lektorským řízením.
RESEARCH OF IMPORTANT GROUNDWATER SOURCES OF CZECHSAXONY TRANSBORDER REGION

\section{ECKHARDT, P.'; ROZMAN, D. ${ }^{1,2}$; HRKAL, Z. ${ }^{1,2}$; NOL, $0 .^{3}$}

'TGM Water Research Institute, p.r.i.

${ }^{2}$ Faculty of Science, Charles University

${ }^{3}$ Czech Geological Survey

Keywords: groundwater - numerical model groundwater use - groundwater protection

An interesting and useful topic that can be addressed within the European Union is the issue of transboundary aquifers. Groundwater is often used as an important water resource on both sides of a common state border and can therefore be affected by cross-border waters. The international project ResiBil, ongoing in 2016-2020, was focused on the joint protection of significant aquifers in the Czech-Saxon border area. The project focused on areas of Cretaceous sediments of Děčínský Sněžník, Czech-Saxon Switzerland and the Lužické Mts. The aim of the ResiBil project was to determine the balance, evaluate the possibility of long-term use of groundwater resources and sustainable management of them, depending on the expected impacts of climate change. The performed studies and models showed, that the reason for changes in the water regime and water balance in the landscape are, to varying degrees, both climatic and anthropogenic influences. However, the use of groundwater has significant reserves in the project area.

DOI: 10.46555/VTEI.2020.07.001 